\title{
Metropolitan Regions as a Changing Policy Concept in a Comparative Perspective
}

\author{
Carola Fricke ${ }^{1}$ (D)
}

Received: 26 November 2015 / Accepted: 11 October 2016 / Published online: 1 November 2016

(c) Springer-Verlag Berlin Heidelberg 2016

\begin{abstract}
In Europe, metropolitan policies emerge in a multi-scalar system of supranational, national and regional scales. Besides national policies on metropolitan issues, more and more European policies address metropolitan regions. They propose varying attributes of what characterizes a metropolitan region, for instance, defining them as functional and statistical areas, or as nodes for European spatial development. These conceptualizations of metropolitan regions have implications for institutional forms of metropolitan governance. However, existing research has not yet comparatively explored the development of metropolitan concepts in national and supranational policy contexts. This paper compares the changing concepts of metropolitan regions in the European Union, France and Germany. It raises the question of how different policies conceptualize metropolitan regions. Thereby, the paper proposes a comparative perspective on concepts in policies addressing metropolitan regions, such as policy documents, planning strategies, regulations or reports. It analyses shifts in metropolitan policies by describing the change of concepts and the reference to frames of spatial development such as polycentricity, competitiveness or integrated development. Three analytical perspectives contribute to understanding the change of metropolitan policies. First, the comparison of concepts in different
\end{abstract}

A previous version of the paper was presented at the RC21 Conference 'The Ideal City: between myth and reality; Representations, policies, contradictions and challenges for tomorrow's urban life', Urbino, Italy, 27-29 August 2015.

\section{Carola Fricke \\ c.fricke@isr.tu-berlin.de}

1 Institut für Stadt- und Regionalplanung, Technische Universität Berlin, Hardenbergstraße 40a, 10623 Berlin, Germany national and supranational policy contexts develops an understanding of metropolitan regions beyond national specificities. Second, a historical comparison contributes to understanding changes in metropolitan concepts since the late 1990s. And third, analysing the development of metropolitan policies comparatively explores similarities of concepts and frames between policy contexts, despite differences in institutional settings.

Keywords Metropolitan regions · Germany · France · European Union $\cdot$ Spatial planning concepts

\section{Metropolregionen als ein sich wandelndes Policy- Konzept im Vergleich}

Zusammenfassung Metropolitane Politiken (policies) in Europa entstehen innerhalb eines Mehrebenensystems, bestehend aus der supranationalen, nationalen und regionalen Ebene. Neben nationalen Politiken zu metropolitanen Themen adressieren zunehmend auch europäische Policies Metropolregionen. Diese schlagen verschiedene Attribute vor, um Metropolregionen zu charakterisieren und definieren diese beispielsweise als funktionale oder statistische Gebiete oder als Knotenpunkte der räumlichen Entwicklung in Europa. Diese Konstruktionen von Metropolregionen wirken sich auf institutionelle Formen von metropolitaner Governance aus. Jedoch befassen sich bisherige Forschungsansätze kaum mit der Entwicklung von metropolitanen Konzepten im nationalen und europäischen Kontext aus vergleichender Perspektive. Dieser Beitrag nimmt daher eine Gegenüberstellung sich wandelnder Konzepte von Metropolregionen in verschiedenen Policy-Kontexten vor, genauer, in der Europäischen Union sowie in Deutschland und Frankreich. Es stellt sich die Frage, wie nationale 
und supranationale Politiken Metropolregionen konzeptualisieren. Dabei vergleicht der Beitrag Definitionen in Policies, die Metropolregionen adressieren, unter anderem in strategischen Planungen, politischen Dokumenten, Verordnungen oder Berichten. Der Wandel von Metropolenpolitik wird analysiert, wobei Metropolregionen als Konzepte aufgefasst werden, die auf Deutungsrahmen der räumlichen Entwicklung wie beispielsweise Polyzentralität, Wettbewerbsfähigkeit oder integrierten Entwicklung beruhen. Der Beitrag untersucht die Veränderung von metropolitanen Politiken aus drei analytischen Perspektiven: Erstens trägt der Vergleich von metropolitanen Konzepten in nationalen und supranationalen Policy-Kontexten $\mathrm{zu}$ einem Verständnis von Metropolregionen jenseits von nationalen Eigenheiten bei. Zweitens dient eine historische Zusammenschau dazu, den Wandel von metropolitanen Konzepten und Paradigmen seit den späten 1990er-Jahren besser zu verstehen. Drittens zeigt die Gegenüberstellung von metropolitanen Politiken Ähnlichkeiten zwischen Konzepten und Deutungsrahmen trotz unterschiedlicher institutioneller Rahmenbedingungen auf.

Schlüsselwörter Metropolregionen · Deutschland · Frankreich · Europäische Union · Konzepte der räumlichen Entwicklung

\section{Introduction}

In Europe, policies on metropolitan regions are influenced by various national specificities, such as the structure of the urban system, the institutional context or the planning tradition. Moreover, metropolitan policies emerge in a multi-scalar context, characterized by interdependencies between supranational, national and regional scales. ${ }^{1}$ This paper compares the development of metropolitan regions as a policy concept in the European multi-scalar context, focusing on the examples of France, Germany and the European Union (EU). France and Germany represent two instructive examples of metropolitan policies, because in both cases national policies explicitly addressing metropolitan regions have changed importantly in the past two decades. The comparison of these two national contexts contributes to understandings of metropolitan policies in Europe, as both are member states of the EU, yet differ in terms of their political, administrative and planning systems. Thus, they provide two different examples of how metropolitan

\footnotetext{
1 The term multi-level system refers to interdependencies between urban, regional, national and supranational levels of government in the context of European integration, see for instance Hooghe and Marks (2001) or Bache and Flinders (2004); the term scale refers to a hierarchically ordered, bounded space, which is socially constructed, see Delaney and Leitner (1997: 93).
}

policies are constructed in Western Europe. The metropolitan dimension in EU policies forms the third case. Studying European in contrast to national policies contributes importantly to a more refined understanding of how metropolitan policies change in a multi-scalar setting. Furthermore, studying metropolitan policies in the EU as a separate case permits the identification of general shifts in concepts and frames of metropolitan regions, because the supranational policy discourse influences and depends on a mix of national and supranational incentives and creates innovative policy opportunities, for instance, via funding programs.

Metropolitan policies are defined as public policies which aim at the development of metropolitan regions in spatial, economic, or infrastructural terms. And although metropolitan regions have been the object of academic debate and policy practice ever since processes of urban development expanded beyond the administrative borders of cities, there is still ambivalence in the terminology. Similar to the concept city region, the term metropolitan region has overlapping and multi-disciplinary meanings (Neuman/Hull 2009). Metropolitan region is thus a "plastic term" (Rossignolo/Toldo 2008: 65), whose lack of conceptual clarity and flexible character leaves room for different meanings. The metropolitan region can be seen as an instrument for spatial planning (Fürst 2008: 219) and normative expectations related to the concept render it attractive for policy-making (Rodríguez-Pose 2008: 1035).

Comparisons of metropolitan regions in Europe have broadened understanding of metropolitan governance and showed the variety of institutional forms for organizing cityregional cooperation (Salet/Thornley/Kreukels 2003; van den Berg/van der Meer/Otgaar et al. 2006). Several studies have compared metropolitan policies on a national level from diverse perspectives (Herrschel/Newman 2002; Brenner 2004; Heinelt/Kübler 2005).

However, a comparison of national policies from a constructivist perspective is still missing. This paper contributes to the existing research by comparing metropolitan policies with regard to changes in their central concept as well as underlying frames. It raises the question of how metropolitan regions as spatial concepts have developed in the past two decades. The objective of the paper is, first, to describe the change of spatial concepts and underlying frames since the 1990s in three different policy contexts - France, Germany and the EU - in order to categorize existing understandings in policy practice. Second, the paper looks beyond national debates and case studies of metropolitan regions, relating them to different conceptualizations of metropolitan regions in the academic debate in order to carve out similarities and differences in the use of the concept.

After introducing central strands of the academic literature on metropolitan regions, which relate to spatial con- 
cepts such as polycentricity, competiveness or integrated development (Sect. 2), Sect. 3 specifies how the analysis of spatial concepts contributes to understanding shifts in underlying frames and paradigms. In Sect. 4, metropolitan policies in France, Germany and the EU are briefly characterized, tracing co-existing conceptualizations and shifts in the policy framing. The three case descriptions draw on secondary literature as well as the analysis of strategic documents, policy programs and visual representations. The comparison in Sect. 5 discusses complementary concepts of metropolitan regions in France, Germany and the EU. Despite similarities in the emergence of metropolitan regions due to shifts in planning paradigms, different understandings prevail in the concrete elaboration of policy instruments. Thereby, the paper shows that policy concepts can be influenced by the exchange of ideas, yet also change according to specificities of the national or supranational context.

\section{Metropolitan Regions and Policies in the Academic Debate}

This section discusses the existing literature on metropolitan regions from two different perspectives. First, it presents a number of authors comparing metropolitan regions as well as national policies on metropolitan regions in European states. The second part outlines the different conceptualizations of metropolitan regions in the academic debate, informing the categorization and interpretation of policy concepts in the empirical analysis.

\subsection{Comparative Perspectives on Metropolitan Regions and Metropolitan Policies in Europe}

Comparative approaches to metropolitan regions or policies referring to metropolitan regions in Europe can be classified into two main analytical perspectives relevant for the following analysis. One approach is to compare metropolitan regions as individual cases of governance or city-regional cooperation. Often, these comparisons are collections of individual case studies on governance institutions and their context, written by different authors. The edited volume by Salet, Thornley and Kreukels (2003), for instance, compiles case studies on metropolitan governance in Europe with a specific focus on spatial planning. Another cross-national analysis of governing metropolitan regions by Heinelt and Kübler (2005) combines contributions on national policies as well as on individual metropolitan regions with a focus on Western Europe. Similarly, van den Berg, van der Meer, Otgaar et al. (2006) compare metropolitan and regional partnerships in Europe, assessing their success and focusing on their organizational structure as well as on con- text factors for cooperation. While all these contributions have collected important evidence on cases of metropolitan governance in Europe, few engage in more structured comparisons or generalizations beyond the case studies.

A second set of studies compares national policies on metropolitan regions in Europe, often promoting the thesis that the national context for metropolitan governance remains important beyond the potential and incentives in individual metropolitan regions. Most of the authors characterize metropolitan policies in national contexts from institutionalist or neo-regionalist perspectives. One example is the early overview of metropolitan policies in Western Europe by Lefèvre (1998). He compares different types of metropolitan government based on evidence from specific cases, such as Greater London, Rotterdam or Barcelona, as well as from national approaches to metropolitan policies, for example, in France, the US and Italy. Furthermore, Herrschel and Newman (2002) conduct a structured comparison of city-regional governance in England and Germany along common dimensions, building on different theoretical approaches and thereby contributing to the discussion on 'new regionalism' in Europe. Brenner (2004) discusses the formation of metropolitan governance in Western Europe with a strong theoretical and critical positioning. He emphasizes the role of national welfare states for the emergence of metropolitan institutions in the context of neo-liberalization and interprets them as processes of state rescaling. From an institutionalist perspective, Jouve (2005) sketches out the general developments of metropolitan policies related to territorial and administrative reforms in Europe. He emphasizes the important role of the state in institutional reforms of urban government. Zimmermann (2016), furthermore, outlines a systematic comparison of metropolitan policies regarding welfare and planning systems as well as administrative structures in France, England, Italy and Germany.

These comparative accounts of political organization as well as national policies on metropolitan regions have broadened understanding of metropolitan governance in Europe importantly. However, a comparison of national policies with regard to their underlying policy frames and conceptualizations of metropolitan regions is still missing.

\subsection{The Metropolitan Region as a Multi-Faceted Concept}

The question of what constitutes a metropolitan region has fuelled continuous debates among planners, politicians and researchers since processes of urbanization changed the re- 


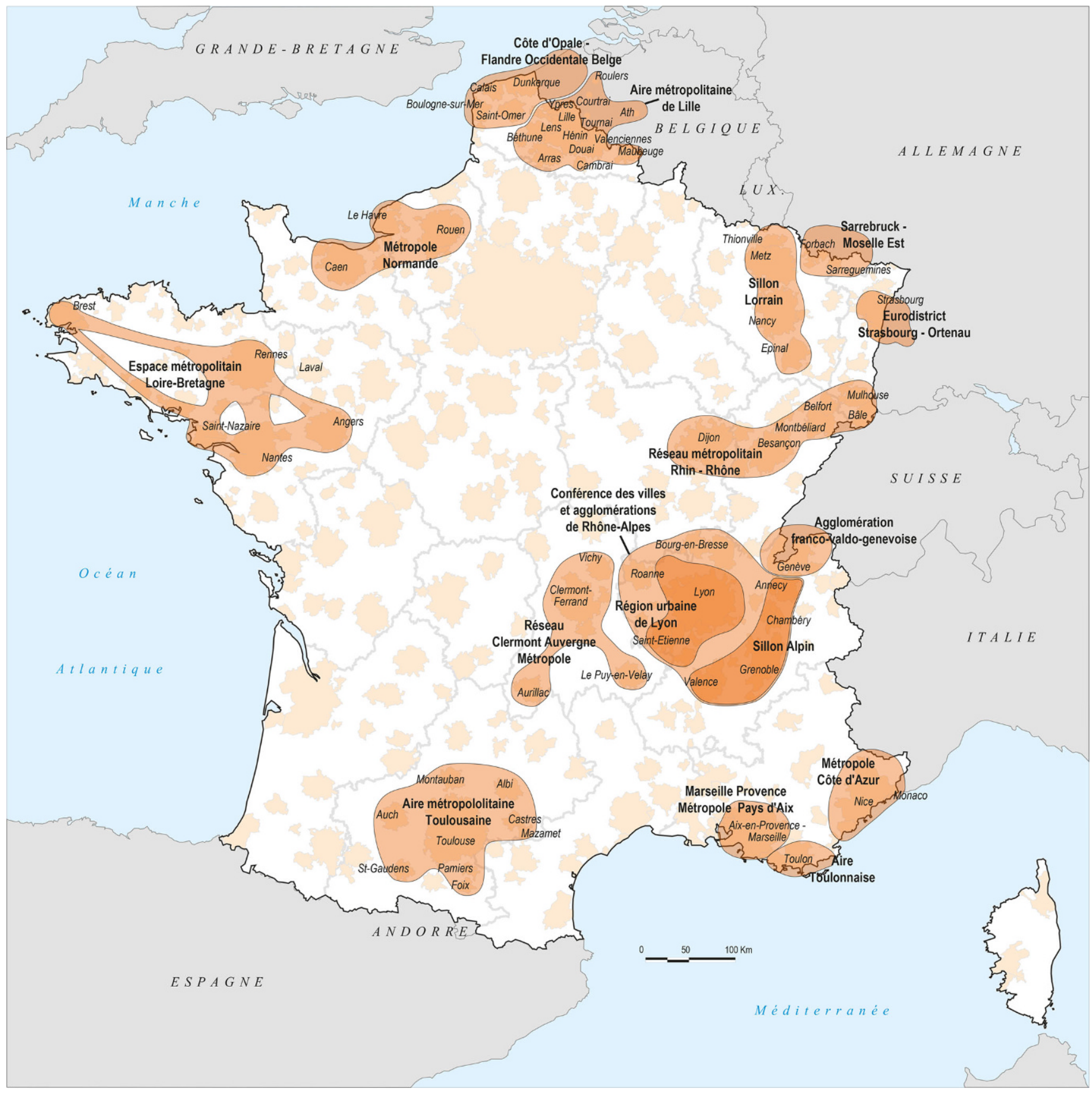

Fig. 1 Results of the call for metropolitan cooperation in France. Source: DATAR (2005)

lationship between the city centre and its surroundings. ${ }^{2}$ Also, definitions vary between different terminologies, such as metropolis, metropolitan region, city region, urban area or agglomeration. When comparing national or supranational policies on metropolitan regions, a central category

\footnotetext{
2 For an overview of the international academic debate concerning the development of city-regional cooperation and in particular of German policy practice, see Zimmermann (2012: 153 ff.), Zimmermann and Heinelt (2012).
}

of comparison is how the concept of a metropolitan region is understood in these different contexts. Thus, the following section aims to trace differences between understandings and specifies the criteria applied for defining metropolitan regions. The purpose of this overview is to deductively develop main categories for structuring the empirical analysis.

For analytical purposes, it is possible to distinguish three main attributes for defining a metropolitan region: first, internal functional interdependence; second, relative importance in the urban system; and third, the need for inter- 
Table 1 Changing terminology and concepts referring to metropolitan regions in France

\begin{tabular}{|c|c|c|c|c|}
\hline & 1960-1990 & $1990 \mathrm{~s}$ & $2000 \mathrm{~s}$ & $2010 \mathrm{~s}$ \\
\hline Terminology & $\begin{array}{l}\text { Métropole d'équilibre } \\
\text { Zone de Peuplement Indus- } \\
\text { triel et Urbain (ZIPU) } \\
\text { communautés urbaines }\end{array}$ & $\begin{array}{l}\text { Aire Urbaine }(1990) \\
\text { reseaux de villes }(1993) \\
\text { projet d'agglomération } \\
(1999)\end{array}$ & $\begin{array}{l}\text { Polycentrisme maille (2002) } \\
\text { pôles de compétitivité }(2004) \\
\text { projet métropolitaine }(2004)\end{array}$ & $\begin{array}{l}\text { métropole, pôle } \\
\text { métropolitain (2010) } \\
\text { métropoles (2014) }\end{array}$ \\
\hline Concepts & $\begin{array}{l}\text { Growth-poles (Perroux), bal- } \\
\text { ancing regional development }\end{array}$ & Polycentricity & Economic clusters & $\begin{array}{l}\text { Administrative juris- } \\
\text { dictions }\end{array}$ \\
\hline
\end{tabular}

local cooperation. First, metropolitan regions can be defined by the relationship "between an urban core and its semi-urban and rural hinterland" (Rodríguez-Pose 2008: 1026). These intra-metropolitan functional interdependencies are often measured in terms of commuter flows or service exchanges. The second criterion is the importance of metropolitan regions in the national, European or international urban system. This attribute refers to functions which metropolitan regions fulfil in an urban hierarchy, representing nodes in a wider network, motors or poles for economic growth, as agglomerations of population or capital. ${ }^{3}$ Third, metropolitan regions can be defined as political actors or territorial levels of government that coordinate the subunits in governance organizations (Lefèvre 1998; Kübler 2003; Blatter 2007).

These understandings of metropolitan regions build on different disciplines and strands of the academic debate, which are understood as complementary. Thereby, it is important to recognize that no one single definition of "the metropolitan' prevails, but multiple understandings compete with each other. The following analysis builds on this multi-faceted nature of the concept, because it expects to find differences in the interpretation and application of the concept between national and supranational contexts. Assuming a complementarity of understandings thus allows analysis of the "[...] different constructions of the city region concept [that] are being captured and employed in different ways, in different places, and at different times [...]" (Harrison/Growe 2014: 38). Accordingly, a metropolitan region is rather to be seen as a general concept, which can be combined with local (or national) place development ideas (Healey 2009).

\section{Spatial Planning Concepts and Re-Framing in Metropolitan Policies}

Metropolitan policies in national as well as European contexts reflect different conceptualizations of what constitutes a metropolitan region. Therefore, metropolitan policies are widely defined as a field of public policy relevant to the spa-

\footnotetext{
3 This characteristic of metropolitan regions is related to the debates on global city regions (Scott 2004) or world cities (Knox/Taylor 1995).
}

tial, economic, or infrastructural development of metropolitan or city-regional areas and cutting across different policy sectors (Zimmermann 2012: $153 \mathrm{f}$.). At the national and European level, metropolitan regions are addressed mostly in spatial planning, as well as urban and regional policies. This section exemplifies the links between the different conceptualizations of metropolitan regions and more general frames of spatial development, which will inform the overall interpretation of policy shifts.

Analysing the definitions of metropolitan regions as spatial concepts offers a way of understanding metropolitan policies in different contexts. Notably, Healey (2004) analysed the ways in which spatial organization and places are represented in strategic plans by carving out "frames of reference, organizing concepts and metaphors [...] of strategic spatial planning" (Healey 2004: 46). Similarly, Alden (2006: 23 f.) states that theoretically based paradigms of regional development and spatial planning resonate in planning practice and policy-making, referring to the context of European spatial planning. Here, spatial concepts are often explicitly expressed in spatial metaphors, understood as "ways of describing the spatial structure of Europe in a manner that can be easily grasped [...]" (Williams 1996: 97).

The comparison of changing spatial concepts in metropolitan policies builds on metaphors deriving from normative as well as analytical theories of regional and spatial development (Lagendijk 2006; Küpper 2008: 350 ff.). First, metropolitan policies draw on the concept of economic competitiveness between places. In the EU context, this idea of endogenous or place-based development is related to the policy goals of the Lisbon Agenda. Second, balanced or integrated development refers to cross-sectorial approaches in a comprehensive understanding of spatial planning. In the European context, this also implies an orientation towards territorial cohesion (Waterhout 2007). Third, the concept of polycentricity originates in analytical understandings of relations between places in an urban system. In the context of metropolitan policies, this concept is related to intra-regional core-periphery relations (Rossignolo/Toldo 2008; Schmitt 2013).

In assessing these concepts and tracing shifts in paradigms on regional and spatial development, the following empirical analysis builds on the re-framing literature. Frame 


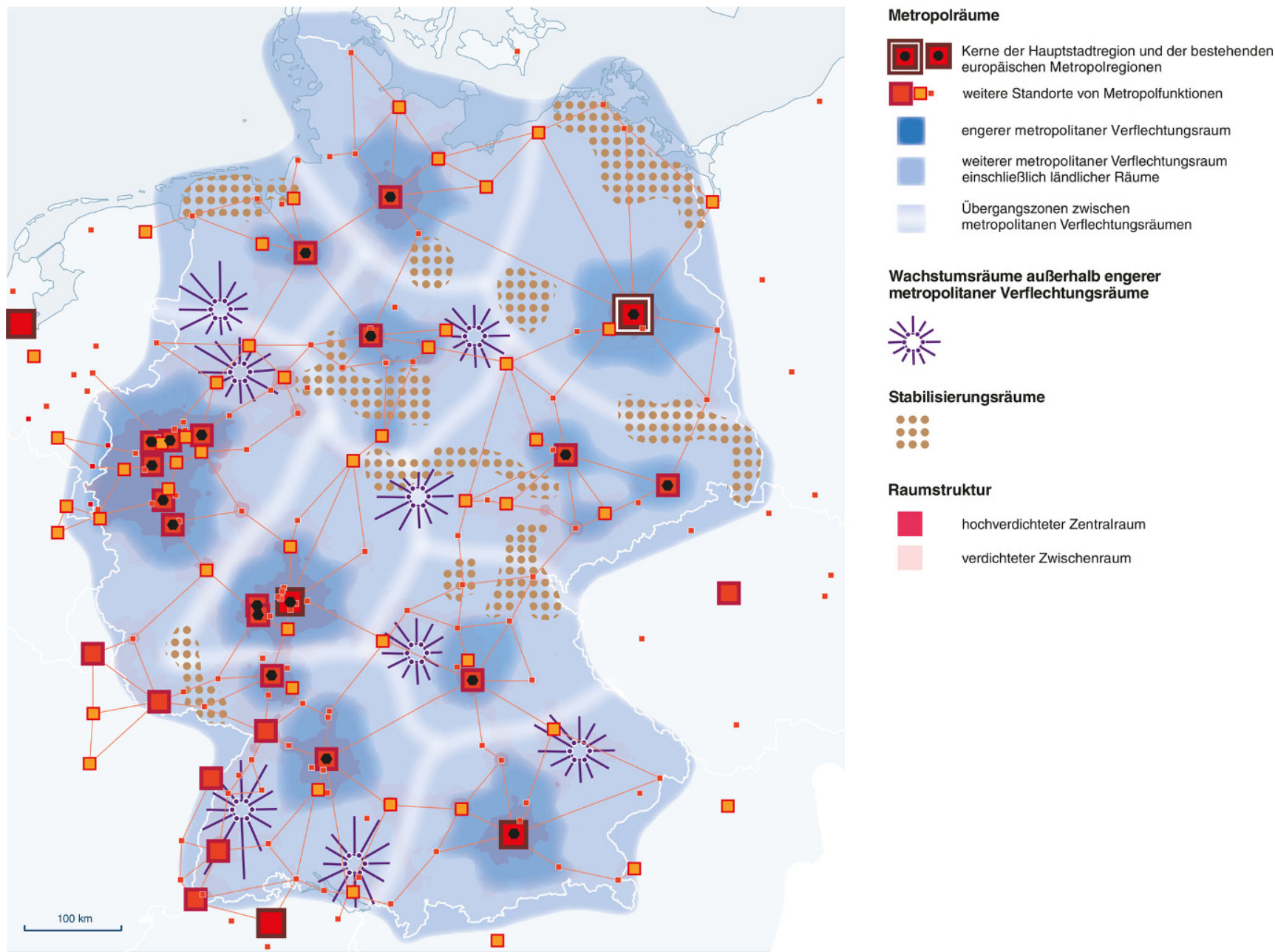

Fig. 2 Spatial Planning Concept Growth and Innovation. Source: BBSR (2006)

analysis contributes to uncovering the contradictions and ambiguities as well as the role of different actors in the policy discourse (Rein/Schön 1993: 162). Policy frames are normative-descriptive structures that guide (inter-) action and provide interpretive schemes of how to solve a specific problem (Rein/Laws 2000: 93, 96). In order to analyse frames in metropolitan policies, the following analysis identifies the policy context by naming the main institutions. The policy discourse, defined as "verbal exchange or dialogue, about policy issues" (Schön/ 1994: 31), is then explored through the main documents and programs on metropolitan regions in each context. Discourse builds the basis for carving out the broader frames and spatial concepts, describing metropolitan regions in relation to the above stated theoretical foundations.

\section{Metropolitan Metaphors in a Multi-Scalar Context}

The following section describes metropolitan policies in three contexts, starting with an overview of metropolitan policies in France, which has the longest tradition of policies explicitly addressing metropolitan regions. In Germany, the topic appeared in the 1990s, while in EU policies a metropolitan dimension has only recently emerged.

\subsection{Metropolitan Policies in France: Balancing the Urban System?}

Metropolitan policies in France take place in a political and administrative system which has experienced decentralization since the 1980s (Kuhlmann 2008). Despite territorial reforms, the French central state remains decisive for spatial planning and for regional development policies. The main planning competences are located at the state level which delegates specific policy issues to the regional 
Table 2 Changing terminology and concepts referring to city regions in Germany

\begin{tabular}{|c|c|c|c|c|}
\hline & $1960-1990$ & $1990 \mathrm{~s}$ & $2000 \mathrm{~s}$ & $2010 \mathrm{~s}$ \\
\hline Terminology & $\begin{array}{l}\text { Verdichtungsräume, Ord- } \\
\text { nungsräume, besonderer } \\
\text { Steuerungsbedarf (1968, } \\
1973,1977,1992)\end{array}$ & $\begin{array}{l}\text { "größere Stadtregionen } \\
{[\ldots] \text { Wachstumsmotoren }} \\
\text { [...] mit teilweise erheblichen } \\
\text { Belastungen" (1993) } \\
\text { große Verdichtungsräume; } \\
\text { europäische Metropolregionen } \\
\text { (1995) }\end{array}$ & $\begin{array}{l}\text { Metropolregionen (2003) } \\
\text { Europäische Metropolregio- } \\
\text { nen (2006) }\end{array}$ & $\begin{array}{l}\text { großräumige Verantwor- } \\
\text { tungsgemeinschaften } \\
\text { (2010) } \\
\text { Überregionale Partner- } \\
\text { schaften (2012) }\end{array}$ \\
\hline Concepts & $\begin{array}{l}\text { Central-places, urban hierar- } \\
\text { chy, integrated development, } \\
\text { balanced functional areas }\end{array}$ & $\begin{array}{l}\text { Competitiveness, international } \\
\text { functions, global/world city } \\
\text { concept }\end{array}$ & $\begin{array}{l}\text { Regional governance, flexi- } \\
\text { ble, voluntary cooperation }\end{array}$ & - \\
\hline
\end{tabular}

Sources: Geschäftsstelle der Ministerkonferenz für Raumordnung (2016); Blotevogel (2001: 161); Zimmermann (2012: 175, 198)

and local levels (Lacour/Delamarre/Thouin 2008). This was reflected in the role of the former national agency for spatial planning and development (Délégation interministérielle à l'aménagement du territoire et à l'action régionale, DATAR), whose work informed the decisions of the ministerial committee for spatial planning (Comité interministériel d'aménagement et de développement du territoire et d'attractivité régionale, CIADT) until 2014.

French policies on metropolitan regions originate from the 1960s, when compensatory policies (Brenner 2004: $149,151)$ were introduced in order to tackle the monocentric urban system and counterbalance the dominance of the French capital by strengthening secondary cities, named métropoles d'équilibres (Lacour/Delamarre/Thouin 2008). Besides, legal frameworks allow inter-municipal forms of cooperation to obtain competences and resources delegated by municipalities and thereby overcome the fragmentation of local government (Lefèvre 2009: 36). In 1999, the law Chevènement introduced new instruments for inter-municipal cooperation (établissement public de cooperation intercommunale, EPCI), among which the communautés urbaines were reserved for urban areas with over 500,000 inhabitants. Borraz and Le Galès characterized the law as a "[...] strong state intervention in the process of building metropolitan governments" (Borraz/Le Galès 2005: 21). Lefèvre (2009: 40) judged it as only a quantitative success based on financial incentives given by the central state.

In the early 2000s, spatial planning in France shifted from a redistributive approach to the assistance of endogenous development, introducing a linked polycentricity (polycentrisme maille, DATAR 2002). This shift expressed itself in the field of metropolitan policies by a call for cooperation launched in 2004 (CIADT/DATAR 2003), which was organized in the form of a competition for metropolitan projects. The call introduced an experimental approach to territorial development with equal opportunities to participate, and built on bottom-up initiatives with little funding from the central state (Geppert 2006: $44 \mathrm{f}$.; Geppert 2009: 262). Fig. 1 shows a selection of city- regional partnerships in monocentric urban areas and polycentric networks between cities that resulted from the call. In 2010, two new legal instruments for inter-municipal cooperation (EPCI) were introduced: the métropole, which can be formed by urban areas with more than 400,000 inhabitants, and the pôle métropolitain, formed by preexisting inter-municipal entities. Currently, the law MAPTAM (modernisation de l'action publique territoriale et d'affirmation des métropoles) and ongoing territorial reforms are expected to have further effects on metropolitan regions and their administrative status (Béhar/Estèbe 2014).

The policy discourse in France developed around three conceptualizations of metropolitan regions: first, as a statistical concept, second, as an administrative territory and, third, as a functional entity. First, a statistical concept defining zones of industrial and urban population (Zone de Peuplement Industriel et Urbain, ZPIU) was replaced by urban zones (Aire Urbaine), consisting of the urban centre and surrounding municipalities with more than $40 \%$ of the population working in the urban centre. And yet, the French concept of agglomération métropolitaine is mainly used as an administrative term (Lefèvre 2000: 296). This secondary understanding as an instrument for inter-municipal cooperation (EPCI) developed according to the legal definitions proposed in the respective reform laws. The third concept of metropolitan regions referred to broader understandings of spatial development, which in the 2000 s emphasized the economic role of cities. Table 1 displays the change in policy discourse from a redistributive understanding of métropoles d'équilibre to a positive framing of metropolitan regions as economic islands in a globalized economy (Lacour/Delamarre/Thouin 2008: 84).

Originally, the policy discourse on metropolitan regions in France built on the idea of polycentricism (Baudelle/ Peyrony 2005: $92 \mathrm{f}$.), expressed in a balanced distribution of the métropole d'équlibre and coinciding with the development objective of territorial cohesion. The call for metropolitan cooperation and cluster policy in the mid2000s, however, was oriented towards competitiveness and 


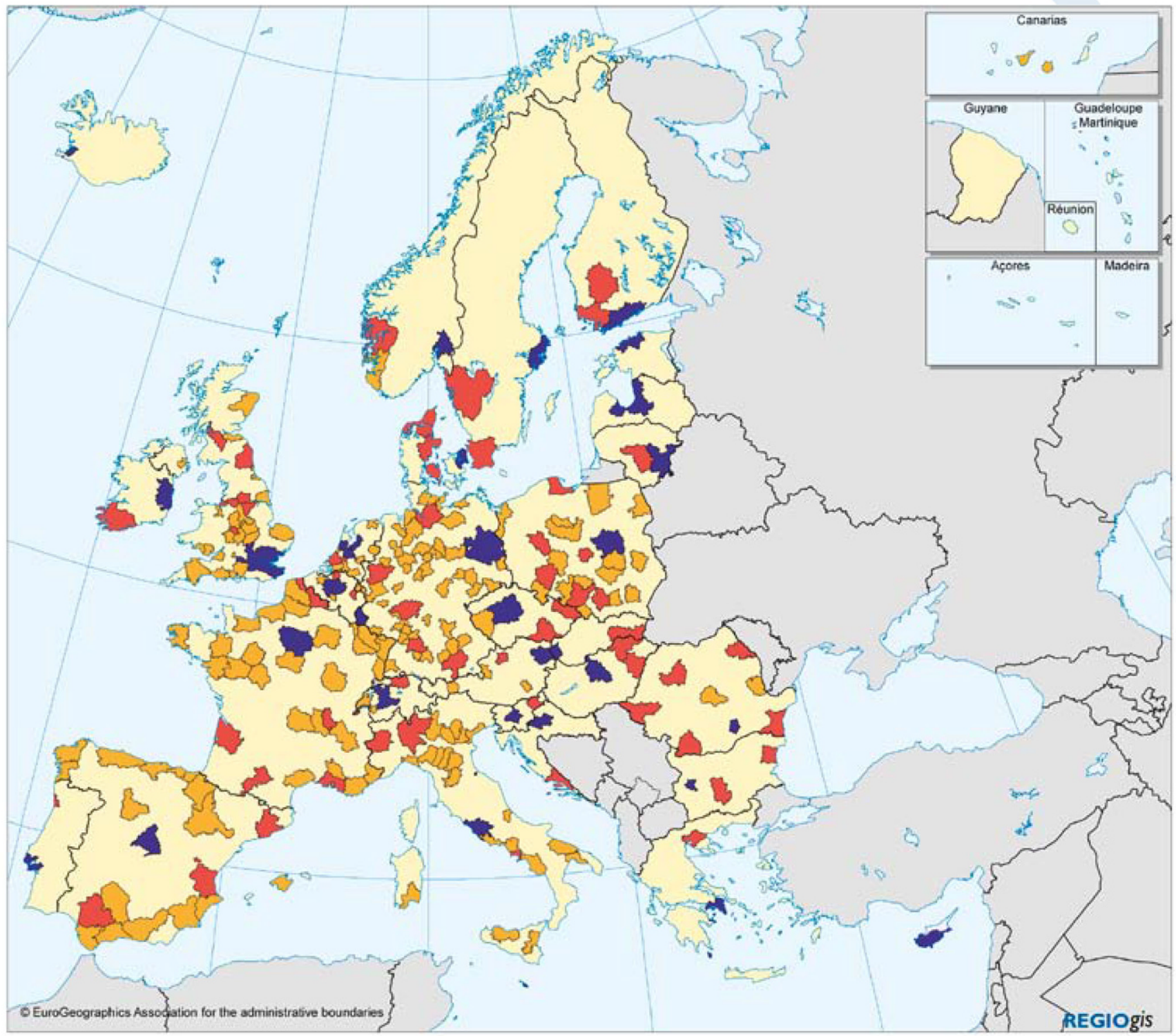

\section{Type of metro region \\ Capital city region \\ Second tier metro region \\ Smaller metro region}

Metro regions definition v. 2009
Sources: Eurostat, DG REGIO

0

$500 \mathrm{Km}$

Fig. 3 Typology of Metropolitan Regions in the European Union. Source: Dijkstra/Poelman (2011: 5)

the knowledge economy (Geppert 2014: 122). It can also be read as a re-discovery of polarization theory in the tradition of François Perroux (Lacour/Delamarre/Thouin 2008: 34). The change of these concepts also illustrates the shift from orchestrated regionalization prescribed by the national state to a central government approach that builds on mobilizing regional incentives and potentials. The most recent national laws on metropolitan governance, however, can be interpreted as an attempt to stipulate the model of successful metropolitan regions, such as Grand Lyon, as an instrument for regional development. 
Table 3 Changing terminology and concepts referring to city regions in the EU

\begin{tabular}{|c|c|c|c|}
\hline & $1990 \mathrm{~s}$ & $2000 \mathrm{~s}$ & $2010 \mathrm{~s}$ \\
\hline Terminology & $\begin{array}{l}\text { Metropolitan region (EU Council } \\
\text { 1999) }\end{array}$ & $\begin{array}{l}\text { City region (EU Council 2007a; EU } \\
\text { Council 2007b), } \\
\text { metropolitan areas (EESC), } \\
\text { functional urban area (ESPON 2007) }\end{array}$ & $\begin{array}{l}\text { Metropolitan regions responsible for sur- } \\
\text { roundings, nodes of networks (EU Council } \\
2011 \text { ), } \\
\text { metropolitan regions as functional areas } \\
\text { (Dijkstra/Poelman 2011) }\end{array}$ \\
\hline Concepts & $\begin{array}{l}\text { Polycentricity, integrated develop- } \\
\text { ment }\end{array}$ & $\begin{array}{l}\text { Service provision and economic growth; } \\
\text { multi-level structure }\end{array}$ & $\begin{array}{l}\text { Polarization vs. partnerships and inte- } \\
\text { grated investments }\end{array}$ \\
\hline
\end{tabular}

\subsection{Metropolitan Regions as a new Spatial Concept in Germany}

Metropolitan policies in Germany take place in a federal system, consisting of the national level, federal states with legislative competences and self-governance on the local level. On the national level, metropolitan regions are defined in spatial planning documents by the Federal Conference of Ministers for Spatial Planning (Ministerkonferenz. für Raumordnung, MKRO), which are prepared by the Federal Institute for Research on Building, Urban Affairs and Spatial Development (Bundesinstitut für Bau-, Stadt- und Raumforschung, BBSR). Until the 1990s, the policy discourse referred to city regions as agglomerations or densely populated areas (Ballungsraum or Verdichtungsraum; see Heinz (2000: 184 ff.); Zimmermann (2012: 172 ff.)). Also, planning policies barely recognized the role of metropolitan regions for economic development, in keeping with the overall goal of ensuring balanced spatial development and equivalent living conditions throughout the national territory (Blotevogel 2001: 162).

In the early 1990s, the general statements for spatial planning introduced metropolitan regions as a new concept. The orientation framework (Raumordnungspolitischer Orientierungsrahmen) stated the overall principle of decentralized concentration and named city regions as areas with considerable burdens (MKRO 1993: 9). The following action framework (Raumordnungspolitischer Handlungsrahmen) introduced the concept of European metropolitan regions as engines of social, economic and cultural development (MKRO 1995: 27). The prefix 'European' referred to the role of metropolitan regions for the development of European space as a whole.

The role of metropolitan regions for growth, innovation and transportation was again emphasized in the visions and strategies for spatial development (MKRO 2006). Fig. 2 shows the spatial planning visions on growth and innovation, and prominently displays metropolitan regions. Recently, the focus of planning policies has become broader, experimenting with large-scale cooperation areas ( großräumige Verantwortungsgemeinschaften). In 2014, a final draft of the updated spatial planning principles revealed shifts in the underlying constitutive logics of metropolitan regions, including the introduction of cross-border metropolitan regions (MKRO 2014: 10).

Table 2 shows the way in which terminology and central concepts in German metropolitan policies have undergone a change in recent decades from a negative to a positive framing. The introduction of European metropolitan regions marks a shift from a problem-oriented, analytical or technocratic perspective towards a development-oriented, strategic-symbolic concept. Accordingly, the metropolitan region replaces the previous terms city region (Stadtregion) and agglomeration (Agglomerationsraum; Schmitt 2009: 64). This political-discursive definition of metropolitan regions as strategic regions (Beier/Matern 2007: 9 ff.) is accompanied by certain expectations and the symbolic framing of policies (Petrin/Knieling 2009).

In the current German debate, three spatial metaphors of metropolitan regions prevail. First, an analytical definition of city regions based on statistical indicators such as population density or urbanization (Verstädterung, in terms of non-agricultural employers, urban design, etc.), which is applied for identifying agglomerations (Verdichtungsräume, BBSR (2012: 157)). Second, a political-normative definition of metropolitan regions as action units referring to institutional forms of city-regional coordination that aim to balance spatial development or problems between the core and surrounding areas (Zimmermann/Heinelt 2012: 61). Governance structures then vary between individual metropolitan regions, ranging from the establishment of territorial jurisdictions to informal networks based on private associations. Third, metropolitan regions in Germany are described as poles for economic growth, referring to the functions of a location in service-providing sectors as well as economic development.

These overlapping or even contrasting metaphors of metropolitan regions contribute to the vague definition of the term (Schmitt 2009), which leaves room for interpretation and makes the concept attractive for policy-makers (Petrin/Knieling 2009: 301). Overall, metropolitan regions in Germany are a voluntary, non-binding concept suggested in federal spatial planning policies, but implemented on the subnational level. Accordingly, they represent only a strategic or symbolic policy frame, with neither consequences 
for territorial reform nor additional funding (Zimmermann/ Heinelt 2012: 69).

These understandings of metropolitan regions build on policy frames originating in different theoretical paradigms. The framing of metropolitan regions in terms of economic competitiveness in the global and European context refers to the concepts of world cities or global cities (Adam/ Göddecke-Stellmann 2002: 515), and leads to an "economization of the discourse on the metropolitan" (Blotevogel 2001: 160). Furthermore, the assumption that metropolitan regions fulfil superior functions in an urban hierarchy is related to Christaller's concept of central places (Petrin/ Knieling 2009: 308).

Schmitt (2009) sees the concept of European metropolitan regions itself as meandering over time, moving away from the traditional goal of balanced development since the 1960s, to a growth-oriented strategy in the mid-1990s, towards a more balance-oriented concept of inner and wider functional areas in the mid-2000s as well as largescale communities of responsibility in the early 2010s. In this long-term perspective, the new federal spatial planning principles represent a discursive shift (Danielzyk 2012: 29, 31) due to increased attention being paid to the role of large agglomerations for territorial development (Scholich 2009: 30 f.). Overall, the German concept of metropolitan regions expresses this dualism between competition and economic growth versus balanced development and provision of basic infrastructures (Aring/Sinz 2006: 48). This dualism even leads to a certain incoherence between the rhetoric exceptionalism behind the earlier concept of metropolitan regions and the inclusiveness of the way in which the concept was implemented. Currently, metropolitan regions in Germany can be interpreted as a 'catch all' concept, covering most of the German territory and including the majority of the population.

\subsection{Emergence of a Metropolitan Dimension in European Policies}

In the EU, metropolitan policies develop in an inter-governmental as well as a supranational policy context. European policy-making involves the Council of Ministers with representatives from the member states' governments responsible for spatial planning and urban development, the European Commission, the European Parliament and consultative bodies and interest groups, such as Metrex and Eurocities. Explicit metropolitan policies are absent, because the EU holds no decision-making competency in this field. Thus, metropolitan regions are addressed only indirectly via regional funding and symbolic spatial policies.

In European policy discourse, the issue of metropolitan regions has recently emerged in documents, statistics, research, and funding. Non-binding declarations are pre- pared by the member states' governments and decided in the Council of Ministers, giving overall orientations for policy development. Several policy declarations on urban and spatial policy since the late 1990s have mentioned metropolitan regions in various ways (Wiechmann 2009).

In 1999, the European Spatial Development Perspective (ESDP; EU Council/European Commission 1999) explicitly discussed the role of metropolitan regions for integrated development and relations between centres and surroundings, with references to the polycentric structure of the European urban system. The Leipzig Charta (EU Council 2007a) and the Territorial Agenda (EU Council 2007b) make more general reference to city regions. In 2010, the Toledo Declaration mentioned metropolitan regions as one scale in the multi-level structure of a European territorial policy (EU Council 2010). The Territorial Agenda 2020 (EU Council 2011), furthermore, refers to metropolitan regions as important nodes in the urban system that are responsible for their surroundings (EU Council 2011: 8), but also as possible contributing factors for territorial polarization (EU Council 2011: 7). Besides, rival metaphors such as city-regional cooperation (EU Council 2007a; EU Council 2007b) and urban-regional partnerships (European Parliament 2008: 13) are also found in the European policy discourse.

However, these policy declarations contain neither substantive definitions of, nor legal consequences for, metropolitan regions. Varying analytical understandings of metropolitan regions have thus evolved and a common statistical definition is absent, due to differences in indicators and thresholds. ESPON (European Spatial Planning Observation Network) proposed a city-regional terminology based on the concept of functional urban areas and related to the spatial planning principle of polycentricity in the European Spatial Development Perspective (Nordregio 2004). Later, an ESPON-study (2007) introduced the distinction between morphological urban areas (MUAs) and functional urban areas (FUAs). ${ }^{4}$ Furthermore, the statistical office of the EU defines metropolitan regions as one particular level of urban areas, which are equivalent to larger urban zones (LAUs) with more than 250,000 inhabitants (European Commission/Directorate-General Regional and Urban Policy/Eurostat 2012). Fig. 3 displays a typology of metropolitan regions distinguishing capital, second tier, and smaller metropolitan regions.

\footnotetext{
${ }^{4}$ Morphological urban areas are defined by population density on the NUTS 5 level as contiguous municipalities above the threshold of 650 inhabitants per square kilometre or with more than 20,000 inhabitants (ESPON 2007: 8). Functional urban areas correspond to the employment pools or labour basins of morphological urban areas (ESPON 2007: 9) and exhibit functional interdependencies of commuting and suburbanization.
} 
Concerning financial instruments for metropolitan regions, the European Regional Development Fund (ERDF) offers tentative funding opportunities for metropolitan regions. In the programming period 2007-2013 metropolitan regions were eligible for ERDF-funding under Article 6 (European territorial cooperation, cf. EU 2006). In the current funding period, starting in 2014, the ERDF is also available for Integrated Territorial Investments (ITI, Article 36, cf. EU 2013; see also Scholze 2014), allowing member states to define metropolitan regions as functional areas.

Table 3 shows that the terminology used for metropolitan regions in European discourse varied over time and that certain actors tend to use specific metaphors for metropolitan regions. Interest groups, such as Metrex or Eurocities, propose multi-faceted understandings of metropolitan regions as administrative-political, but also functional or spatial entities. Supranational institutions, such as the European Commission or the European Parliament coin a more nuanced terminology, differentiating functional areas from political metropolitan regions. Comparing the understandings in the EU context proposed by different institutional actors shows a tension between evidence-based definitions of metropolitan areas couched in more neutral terms based on research and statistics, and an emphasis on the role of metropolitan regions for the development of the European territory. Overall, metropolitan regions in the European context remain a politically weak concept, probably due to the concurrence of the metropolitan to other territorial scales, such as the city or the region. Despite its growing importance in EU discourse, the metropolitan region remains a vague concept with varying meanings, referring to different underlying frames for spatial development. This vagueness originates in the consensual character of European policies as the outcome of a negotiation process based on the smallest common denominator.

\section{Comparing Metropolitan Policies: Similar Concepts Despite Different Contexts?}

In a nutshell, this comparison reveals similarities between the concepts in all three cases, which is rather surprising given the differences in context. Yet, it also shows specificities in the implementation and overall role of metropolitan regions for spatial and territorial development. To begin with, the comparative analysis of metropolitan policies shows similar developments of the discourse in Germany, France and the EU, despite differences in their institutional context as well as spatial planning policies. In all three cases, metropolitan regions became more prominent in the late 1990s and early 2000s due to the concept's openness and its attractiveness for policy-making. The in- troduction of metropolitan regions in Germany (1995) and France (2003), for instance, was closely related to an overall re-orientation of spatial planning policies. Despite differences in their planning cultures, both countries' spatial planning principles originated from the 1950s and traditionally favoured balanced territorial development (Waterhout/Othengrafen/Sykes 2013: 154), in France pursuing the unity of the territory, and in Germany aiming at a parity of living conditions. Yet, in both countries the introduction of metropolitan regions represented a conceptual shift from a regulatory or compensatory approach to a positive framing of agglomerations, based upon a new spatial metaphor emphasizing competitiveness and growth. In the EU context, the increased attention paid to metropolitan regions in the early 2000s coincided with the overall focus of the Lisbon agenda on economic competitiveness. Thus, in all three cases, the emergence of the concept of the metropolitan region was related to a shift towards fostering competitiveness and growth, not only in purely economic terms, but also concerning overall spatial development.

The comparison also shows congruence in how metropolitan regions are defined. Across all policy contexts, metropolitan regions are conceptualized around the attribute of internal as well as external metropolitanization as proposed by the academic literature discussed in Sect. 2 . The first criterion for defining metropolitan regions in terms of their internal interdependency is based on statistical indicators, which refer to population density and numbers of commuters between contingent administrative units. In the EU context, these are labelled functional urban areas (ESPON 2007) or larger urban regions (European Commission/Directorate-General Regional and Urban Policy/ Eurostat 2012), differing only slightly from national statistical concepts, such as the French aire urbaine or the German Verflechtungsraum. The second attribute defines metropolitan regions according to their role in a larger urban or economic system. This is referred to as external metropolitanization and corresponds, for instance, to the definition of the German European metropolitan regions as being characterized by superior economic, cultural or economic functions, as well as to the references to the role of city regions in the overall development of the European territory.

However, this common orientation and similarities in concepts has a rather discursive nature. Metropolitan policies in France, Germany and the EU differ not only in their institutional context, but also regarding the framing and specific conceptualizations of metropolitan regions, as we find important differences in how metropolitan policies implement and organize these ideas in practice. In France, the dominantly administrative understanding of metropolitan regions is put into practice with the help of instruments proposed by national legislation regarding inter-municipal 
cooperation as well as territorial reform. It was only in the mid-2000s that French metropolitan policies changed their approach and launched competitive calls which aroused expectations of national funding and other financial resources. In Germany, metropolitan policies are mainly addressed in visions and strategies of spatial planning which form a symbolic frame of reference for existing instruments of city-regional cooperation. In the EU, explicit metropoli$\tan$ policies are absent. However, tentative references to metropolitan regions could be interpreted as an emerging metropolitan dimension, resulting in a minimal definition in statistical-analytical terms. Especially in Germany and the EU context, metropolitan policies have a more discursive character and function as a political framework, which leaves flexibility for the implementation of various organizational forms and functional interpretations in metropolitan regions.

However, these national and supranational policies on metropolitan regions have not developed in isolation. Due to the horizontal and vertical exchange of concepts and frames between policy contexts, the discourses on metropolitan regions in France, Germany and the EU have mutually influenced one another. In fact, Schmitt (2009: 64) finds the German metropolitan region inspired by the French concept of urban agglomerations. Baudelle and Peyrony (2005: 92 f.) similarly state that the German idea of a polycentric urban system has influenced French spatial planners in developing the principle of polycentricity. Furthermore, national concepts have also influenced the European policy discourse. Both German and French planning ideas contributed to the development of the European spatial planning policy. Especially French spatial planning has also influenced the European Spatial Development Perspective as well as regional policies (Scholles 2009: 136). Meanwhile, the meetings on a European level between the national representatives responsible for spatial planning have diffused and consolidated the idea that agglomerations play an important role in economic and spatial development. For instance, when German federal planning institutions introduced metropolitan regions on the national level in the mid-1990s, they were simultaneously engaged in the policy process leading to the European Spatial Development Perspective (Schmitt 2009: 64), stating explicitly that metropolitan regions were to be assigned as part of this initiative (MKRO 1995: 27).

Moreover, the evolvement of an implicit metropolitan dimension in the EU context is an instructive example of how the concept of metropolitan regions has diffused and been mobilized by different actors. The way in which EU policy documents, statistics and programs address metropolitan regions shows that metropolitan regions have become a policy issue beyond national spatial planning and urban policies. Yet, the vagueness of the concept in the EU pol- icy discourse also shows that in the context of a lack of competences and concurring interests among policy-makers, the multi-faceted descriptions of metropolitan regions in both academic debate and in practice can be a necessary condition for the popularity and attractiveness of the concept.

\section{Conclusion}

In conclusion, the comparison of metropolitan policies in France, Germany and the EU has shown that since the 1990s conceptualizations of metropolitan regions have shifted from a negative to a positive perception and towards a rhetoric emphasis on competitiveness. Despite similarities between the main definitions of metropolitan regions, which refer to underlying concepts of city-regional cooperation and their relevance for spatial and economic development, metropolitan policies in the three cases have taken various forms and focused on different instruments.

Beyond these similarities and differences between metropolitan policies in the three contexts, two main generalizations can be drawn concerning the nature of the metropolitan region as a political and spatial concept. First of all, all three policies on metropolitan regions have been characterized by a symbolic rather than material agenda, in which the metropolitan region is a multi-faceted concept that can be filled up with different meanings. This conceptual vagueness contributes to the attractiveness of this 'plastic term' and was the focus of this analysis of policy concepts and related frames for spatial development. The comparison of two national and one supranational cases has thereby contributed to a better understanding of the concept beyond national perspectives and methodological nationalism. The comparison of metropolitan policies in three different cases permits only limited causal inference, but nonetheless provides initial indications on the emergence and translation of policy concepts. Looking at policy changes in national and supranational contexts, the comparison shows that individual institutions, planning traditions and policy frameworks remain decisive, but are more and more influenced by upcoming academic concepts, as well as the international exchange of policy ideas. Second, the analysis of these developments of metropolitan policies and the construction of metropolitan regions as an issue in the EU context has wider implications for the role of regional policies, spatial planning and the territorial structure in Western Europe. As outlined in the three cases, metropolitan policies can be interpreted as an attempt to tackle contemporary spatial developments, such as urbanization, urban sprawl and the resulting needs for cooperation, in more practical terms. From a constructivist perspective, however, the emergence of metropolitan regions as a policy 
concept also coincided with general discursive shifts in regional and spatial policies in France, Germany and the EU towards a paradigm of competiveness.

Furthermore, the comparison contributes to the existing literature on metropolitan regions and metropolitan policies in three main ways. First, analysing the changes of policy concepts in three contexts adds a constructivist and processual perspective to existing comparisons of metropolitan policies in Europe. This not only allows the mapping of the current status quo in different countries, but also the identification of similarities in their focus and development over time. Second, these policy changes in terms of concepts and frames were analysed based on an overview of the main streams of the academic debate on metropolitan regions. It thereby became evident that these different policy orientations can be linked to waves of attention to specific topics and to translations of new academic concepts into policy practice. Third, understanding metropolitan regions as a political concept allows inferences to be drawn on more general ideas and frames of spatial development. Metropolitan policies are not analysed here as isolated systems, but rather in the context of more general shifts in political fields dealing with territorial changes.

The comparison, however, indicates the need to further explore two aspects of how metropolitan policies translate between contexts. First, further research is necessary to explain the exchange and mobility of ideas between policy contexts, especially with regard to underlying motivations and coalitions of actors. Second, future analysis should investigate the role of metropolitan actors in the formation and implementation of national and European conceptualizations. Actors on the metropolitan level are assumed to play an important role due to the vagueness of the policy concept of metropolitan regions, which - either as an empty signifier or as a window of opportunity - leaves room for re-interpretation and adjustment to local specificities.

\section{References}

Adam, B.; Göddecke-Stellmann, J. (2002): Metropolregionen: Konzepte, Definitionen und Herausforderungen. In: Informationen zur Raumentwicklung 9, 513-525.

Alden, J. (2006): Regional Development and Spatial Planning. In: Adams, N.; Alden, J.; Harris, N. (eds.): Regional development and spatial planning in an enlarged European Union. Aldershot, $17-40$.

Aring, J.; Sinz, M. (2006): Neue Leitbilder der Raumentwicklung in Deutschland. In: disP - The Planning Review 165, 2, 43-60.

Bache, I.; Flinders, M.V. (eds.) (2004): Multi-level governance. Oxford, New York.

Baudelle, G.; Peyrony, J. (2005): Le polycentrisme en France: cheminement d'un concept. In: DATAR - Délégation à l'aménagement du territoire et à l'action régionale (ed.): Territoire 2030. Paris, 89-101.

BBSR - Bundesinstitut für Bau-, Stadt- und Raumforschung (2006): Neue Leitbilder der Raumentwicklung: Leitbild Wachstum und Innovation. http://www.bbr.bund.de/BBSR/DE/Raumentwicklung/
RaumentwicklungDeutschland/Projekte/Leitbild1/Leitbild1

KarteRepro.jpg?_blob=publicationFile\&v=3 (August 4, 2016).

BBSR - Bundesinstitut für Bau-, Stadt- und Raumforschung (2012): Raumordnungsbericht 2011. Bonn.

Béhar, D.; Estèbe, P. (2014): Paris, Lyon, Marseille, les Régions, face aux Métropoles ou tout contre l'État? In: Revue Urbanisme 49, $19-21$.

Beier, M.; Matern, A. (2007): Stadt-Umland-Prozesse und interkommunale Zusammenarbeit: Stand und Perspektiven der Forschung. Hannover. = Arbeitsmaterial der ARL 332.

Blatter, J. (2007): Governance - theoretische Formen und historische Transformationen. Politische Steuerung und Integration in Metropolregionen der USA (1850-2000). Baden-Baden.

Blotevogel, H.H. (2001): Die Metropolregionen in der Raumordnungspolitik Deutschlands: Ein neues strategisches Raumbild? In: Geographica Helvetica 56, 3, 157-168.

Borraz, O.; Le Galès, P. (2005): France: the intermunicipal revolution. In: Denters, B.; Rose, L.E. (eds.): Comparing local governance: Trends and developments. Houndmills, Basingstoke, New York, $12-28$.

Brenner, N. (2004): New state spaces: Urban governance and the rescaling of statehood. Oxford, New York.

CIADT - Comité interministériel d'aménagement et de développement du territoire; DATAR - Délégation à l'aménagement du territoire et à l'action régionale (2003): Pour un rayonnement européen des métropoles françaises: Éléments de diagnostic et orientations. Paris.

Danielzyk, R. (2012): Der raumordnungspolitische Metropolendiskurs - Konstruktion von (neuen) Peripherien? In: disP - The Planning Review 48, 2, 27-33.

DATAR - Délégation à l'aménagement du territoire et à l'action régionale (2002): Aménager la France de 2020: mettre les territoires en mouvement. La Documentation française. Paris.

DATAR - Délégation à l'aménagement du territoire et à l'action régionale (2005): France: Résultats de l'appel à coopération métropolitaine. http://zonages.territoires.gouv.fr/cooperationmetropolitaine-2005 (August 19, 2016).

Delaney, D.; Leitner, H. (1997): The political construction of scale. In: Political Geography 16, 2, 93-97.

Dijkstra, L.; Poelman, H. (2011): Regional typologies: a compilation. Brussels. = European Union, Regional Policy, Regional Focus 01/2011.

ESPON - European Spatial Planning Observation Network (2007): Project 1.4.3: Study on Urban Functions. Final Report. Luxembourg.

EU - European Union (2006): REGULATION (EC) No 1080/2006 on the European Regional Development Fund and repealing Regulation (EC) No 1783/1999: REG (EC) 1080/2006. Brussels.

EU - European Union (2013) REGULATION (EC) No 1303/2013 on the common provisions of the European Regional Development Fund [...] repealing Council Regulation (EC) No 1083/2006: REG (EC) 1303/2013. Brussels.

EU Council - Council of Ministers responsible for Spatial Planning; European Commission (1999): European spatial development perspective (ESDP): Towards balanced and sustainable development of the territory of the European Union. Brussels.

EU Council - Council of Ministers responsible for Spatial Planning and Urban Development (2007a): Leipzig Charta on Sustainable European Cities. Brussels.

EU Council - Council of Ministers responsible for Spatial Planning and Urban Development (2007b): Territorial Agenda of the European Union: Towards a More Competitive and Sustainable Europe of Diverse Regions. Agreed on the occasion of the Informal Ministerial Meeting on Urban Development and Territorial Cohesion. Leipzig.

EU Council - Council of Ministers responsible for Spatial Planning and Urban Development (2010): Toledo Declaration. Informal Ministerial Meeting on Urban Development. Toledo. 
EU Council - Council of Ministers responsible for Spatial Planning and Territorial Development (2011): Territorial Agenda of the European Union 2020: Towards an Inclusive, Smart and Sustainable Europe of Diverse Regions. Agreed at the Informal Ministerial Meeting of Ministers responsible for Spatial and Territorial Development. Gödöllő

European Commission; Directorate-General Regional and Urban Policy; Eurostat (2012): Defining urban areas in Europe. http:// ec.europa.eu/eurostat/documents/4313761/4311719/Metro_reg_ Defining_urban_areas (August 19, 2016).

European Parliament, Committee on Regional Development (2008): Report on the Follow-up of the Territorial Agenda and the Leipzig Charter: Towards a European Action Programme for Spatial Development and Territorial Cohesion (2007/2190(INI)): Session Document. Brussels.

Fürst, D. (2008): Metropolregionen, Wissensregion und Governance. In: Raumforschung und Raumordnung 66, 3, 219-229.

Geppert, A. (2006): L'appel à coopération métropolitaine: un décryptage. In: Revue Urbanisme 28, 44-46.

Geppert, A. (2009): Polycentricity: can we make it happen? From a concept to its implementation. In: Urban Research and Practice $2,3,251-268$.

Geppert, A. (2014): France, drifting away from the "regional economic" approach. In: Reimer, M.; Getimis, P.; Blotevogel, H.H. (eds.): Spatial planning systems and practices in Europe: A comparative perspective on continuity and changes. London, 109-126.

Geschäftsstelle der Ministerkonferenz für Raumordnung (2016): Übersicht über die Beschlüsse der Ministerkonferenz für Raumordnung. Stand: März 2016. http://www.bmvi.de/SharedDocs/DE/ Anlage/Raumentwicklung/uebersicht-mkro-beschluesse-19672016.pdf?_blob=publicationFile (August 19, 2016).

Harrison, J.; Growe, A. (2014): From places to flows? Planning for the new 'regional world' in Germany. In: European Urban and Regional Studies 21, 1, 21-41.

Healey, P. (2004): The Treatment of Space and Place in the New Strategic Spatial Planning in Europe. In: International Journal of Urban and Regional Research 28, 1, 45-67.

Healey, P. (2009): City Regions and Place Development. In: Regional Studies 43, 6, 831-843.

Heinelt, H.; Kübler, D. (eds.) (2005): Metropolitan governance: Capacity, democracy and the dynamics of place. London. = ECPR studies in European political science 37.

Heinz, W. (2000): Interkommunale Kooperation in Stadtregionen: das Beispiel der Bundesrepublik Deutschland. In: Heinz, W. (ed.): Stadt und Region - Kooperation oder Koordination? Ein internationaler Vergleich. Berlin, 169-274. = Schriften des Deutschen Instituts für Urbanistik 93.

Herrschel, T.; Newman, P. (2002): Governance of Europe's city regions: Planning, policy and politics. London.

Hooghe, L.; Marks, G. (2001): Multi-level governance and European integration. Governance in Europe. Lanham.

Jouve, B. (2005): From government to urban governance in Western Europe: a critical analysis. In: Public Administration and Development 25, 4, 285-294.

Knox, P.L.; Taylor, P.J. (1995): World cities in a world-system. Cambridge, New York

Kübler, D. (2003): "Metropolitan Governance" oder: Die unendliche Geschichte der Institutionenbildung in Stadtregionen. In: Informationen zur Raumentwicklung 8/9, 535-541.

Kuhlmann, S. (2008): Dezentralisierung in Frankreich - Ende der "Unteilbaren Republik"? In: Der moderne Staat - Zeitschrift für Public Policy, Recht und Management 1, 2, 1-21.

Küpper, P. (2008): Metropolen-orientierte Politik und territoriale Kohäsion - Notwendigkeit oder Widerspruch? In: Raumforschung und Raumordnung 66, 4, 346-359.

Lacour, C.; Delamarre, A.; Thouin, M. (2008): 40 ans d'aménagement du territoire. Paris.
Lagendijk, A. (2006): Learning form Conceptual Flow in Regional Studies: Framing Present Debates, Unbracketing Past Debates. In: Regional Studies 40, 4, 385-399.

Lefèvre, C. (1998): Metropolitan Government and Governance in Western countries: A Critical Review. In: International Journal of Urban and Regional Research 22, 1, 9-25.

Lefèvre, C. (2000): Intraregionale Zusammenarbeit zwischen Kernstädten und ihrem Umland in Frankreich. In: Heinz, W. (ed.): Stadt und Region - Kooperation oder Koordination? Ein internationaler Vergleich. Berlin, 277-357. = Schriften des Deutschen Instituts für Urbanistik 93.

Lefèvre, C. (2009): Gouverner les métropoles. Paris.

MKRO - Ministerkonferenz für Raumordnung (1993): Raumordnungspolitischer Orientierungsrahmen: Leitbild für die räumliche Entwicklung der Bundesrepublik Deutschland. Bonn.

MKRO - Ministerkonferenz für Raumordnung (1995): Raumordnungspolitischer Handlungsrahmen: Beschluß der Ministerkonferenz für Raumordnung. Bonn.

MKRO - Ministerkonferenz für Raumordnung (2006): Leitbilder und Handlungsstrategien für die Raumentwicklung in Deutschland. Berlin.

MKRO - Ministerkonferenz für Raumordnung (2014): Leitbilder und Handlungsstrategien für die Raumentwicklung in Deutschland 2013. Beschluss vom 3. Juni 2013. Berlin.

Neuman, M.; Hull, A. (2009): The Futures of the City Region. In: Regional Studies 43, 6, 777-787.

Nordregio (2004): ESPON 1.1.1: Potentials for polycentric development in Europe. Final report. Stockholm.

Petrin, J.; Knieling, J. (2009): Das Bildversprechen der Metropolregion - Potenziale und Risiken einer bildmächtigen Raumkategorie. In: Knieling, J. (ed.): Metropolregionen: Innovation, Wettbewerb, Handlungsfähigkeit. Hannover, 300-322. = Forschungs- und Sitzungsberichte der ARL 231.

Rein, M.; Laws, D. (2000): Controversy, Reframing, and Reflection. In: Salet, W.; Faludi, A. (eds.): Revival of Strategic Spatial Planning. Amsterdam, 93-108.

Rein, M.; Schön, D. (1993): Reframing Policy Discourse. In: Fischer, F.; Forester, J. (eds.): The argumentative turn in policy analysis and planning. Durham, N.C., 145-166.

Rodríguez-Pose, A. (2008): The Rise of the "City-region" Concept and its Development Policy Implications. In: European Planning Studies 16, 8, 1025-1046.

Rossignolo, C.; Toldo, A. (2008): The polycentric 'vocation' of European territories: Towards the construction of the Italian North West and other networking stories. In: Atkinson, R.; Rossignolo, C. (eds.): The re-creation of the European City: Governance, territory and polycentricity. Amsterdam, 65-89.

Salet, W.; Thornley, A.; Kreukels, A. (eds) (2003) Metropolitan governance and spatial planning: Comparative case studies of European city-regions. Abingdon, New York.

Schmitt, P. (2009): Raumpolitische Diskurse um Metropolregionen in Deutschland - Positionen, Kontroversen, Perspektiven. In: Knieling, J. (ed.): Metropolregionen: Innovation, Wettbewerb, Handlungsfähigkeit. Hannover, 60-100. = Forschungs- und Sitzungsberichte der ARL 231.

Schmitt, P. (2013): Planning for Polycentricity in European Metropolitan Areas - Challenges, Expectations and Practices. In: Planning Practice and Research 28, 4, 400-419.

Scholich, D. (2009): Metropolregionen: Paradigmenwechsel der Raumordnung? In: Güldenberg, E.; Preising, T.; Scholles, F. (eds.): Europäische Raumentwicklung: Metropolen und periphere Regionen. Frankfurt am Main, 23-33.

Scholles, F. (2009): Vergleich der Raumplanung und Regionalentwicklung in Deutschland und Frankreich. In: Güldenberg, E.; Preising, T.; Scholles, F. (eds.): Europäische Raumentwicklung: Metropolen und periphere Regionen. Frankfurt am Main, 131-140. 
Scholze, J. (2014): City Regions: The possibility of using EU structural funds for the development of urban-rural partnership in the 2014-2020 funding period. Comparative Policy Analysis. Brussels.

Schön, D.; Rein, M. (1994): Frame Reflection: Towards the Resolution of Intractable Policy Controversies. New York.

Scott, A.J. (ed.) (2004): Global city-regions: Trends, theory, policy. Oxford, New York

van den Berg, L.; van der Meer, J.; Otgaar, A.; Speller, C. (2006). Empowering metropolitan regions through new forms of cooperation: New perspectives on metropolitan governance. Amsterdam.

Waterhout, B. (2007): Territorial Cohesion: The Underlying Discourses. In: Faludi, A. (ed.): Territorial cohesion and the European model of society. Cambridge, 37-60.

Waterhout, B.; Othengrafen, F.; Sykes, O. (2013): Neo-liberalization Processes and Spatial Planning in France, Germany, and the Netherlands: An Exploration. In: Planning Practice and Research $28,1,141-159$.
Wiechmann, T. (2009): Raumpolitische Diskurse um Metropolregionen in Europa - Eine Spurensuche. In: Knieling, J. (ed.): Metropolregionen: Innovation, Wettbewerb, Handlungsfähigkeit. Hannover, 101-132. = Forschungs- und Sitzungsberichte der ARL 231.

Williams, R.H. (1996): European Union Spatial Policy and Planning. London.

Zimmermann, K. (2012): Institutionalisierung regionaler Kooperation als kollektiver Lernprozess? Das Beispiel Metropolregion RheinNeckar. Baden-Baden.

Zimmermann, K. (2016): Metropolenpolitik in polyzentrischen Regionen. In: Danielzyk, R.; Münter, A.; Wiechmann, T. (eds.): Polyzentrale Metropolregionen. Detmold, 100-121.

Zimmermann, K.; Heinelt, H. (2012): Metropolitan Governance in Deutschland: Regieren in Ballungsräumen und neue Formen politischer Steuerung. Wiesbaden. 